Original Contribution

\title{
EFFECT OF DIETARY PHYTOEXTRACTS SUPPLEMENTATION ON GROWTH PERFORMANCE AND BLOOD PARAMETERS OF RAINBOW TROUT (ONCORHYNCHUS MYKISS W.), CULTIVATED IN A RECIRCULATION SYSTEM
}

\author{
K. Georgieva*, G. Zhelyazkov \\ Department of Biology and Aquaculture, Faculty of Agriculture, Trakia University, Stara Zagora, \\ Bulgaria.
}

\begin{abstract}
The present research aimed to examine the effect of dietary phytoextracts supplementation on the growth performance, haematological (white blood cells, red blood cells, hemoglobin, hematocrit) and biochemical (glucose, urea, creatinine, total protein, albumin, ASAT, ALAT) blood parameters of rainbow trout (Oncorhynchus mykiss W.), cultivated in a recirculation system. The fish were divided into 6 groups: one control (C) and five experimental groups in whose food was added phytoextracts of curcumin (EC), paprika (EP), thyme (ET), oregano (EO) and garlic (EG). The inclusion of phytoextracts had no significant effect on growth parameters of fish from EC, EP, ET, EO and EG groups $(\mathrm{P}>0.05)$. Statistically significantly lower feed consumption per unit weight gain was observed in EO group vs $\mathrm{C}(\mathrm{P}<0.05)$. The phytoextract supplementation had significant influence on some of the haematological (white blood cells, red blood cells, hemoglobin) and biochemical (urea, creatinine, total protein, albumin, ASAT, ALAT) blood parameters of rainbow trout.
\end{abstract}

Key words: rainbow trout, Oncorhynchus mykiss, phytoextracts, growth performance, haematological and biochemical blood parameters

\section{INTRODUCTION}

A native species to areas of the Pacific Ocean in Asian and North America is the rainbow trout (Oncorhynchus mykiss), which in relatively short time has been introduced into at least 45 countries and territories (1). Many countries have forbidden the use of antibiotics and refuse to import aquaculture products treated with them. Therefore, researchers looking for methods to develop alternative dietary supplements such as herbs and plants that increase growth performance, health and immune system of cultured fish. There are reports which have documented the positive effects of herbs as appetizers and growth promoters in different aquatic species (2). A number of researchers established higher weight gain and lower feed conversion ratio in

\footnotetext{
*Correspondence to: Kremena Georgieva, Department of Biology and Aquaculture, Faculty of Agriculture, Trakia University, Students Campus, 6014 Stara Zagora, Bulgaria, georgieva.kremena1983@gmail.com
}

different fish species as a result of the addition to extruded pellets plant extracts, such as garlic, oregano, paprika, thyme, curcumin, ginger, echinacea, etc. (3-8). Many authors reported for the positive effect of the inclusion of phytoadditives on fish health and their use of prevents different types of diseases (9-13).

According to some authors the addition of phytoextracts had significant influence on some of haematological and biochemical blood parameters of different fish species $(10,13$, 14). For example, garlic as widely spread plant has antioxidant and anticancer effect and acts like coronary dilator (15). Allicin is the main compound of garlic and gives its characteristic acute smell. Garlic also contains vitamins and minerals. The use of garlic becomes popular in fish farming for raising the activity of nonspecific defense systems and protection against diseases (16). Thyme is an herb known since ancient times and used in different areas of life such as, cosmetic industry and medicin. It 
includes thymol - an essentialoil, which has antiseptic properties, rich in potassium, magnesium, vitamins $\mathrm{A}, \mathrm{C}, \mathrm{E}$ and antioxidants (6). Thymol also has an antimicrobial effect on bacteria, fungi and yeasts (3). The most important therapeutic properties of thyme extract on fish health are antioxidant, antiseptic and digestion stimulant (17). Various investigators have suggested the wide range of therapeutic and/or preventive effects of curcumin on fish health (11).

The present research aimed to examine the effect of dietary phytoextracts supplementation on the growth performance, haematological (white blood cells, red blood cells, hemoglobin, hematocrit) and biochemical (glucose, urea, creatinine, total protein, albumin, ASAT, ALAT) blood parameters of rainbow trout (Oncorhynchus mykiss W.), cultivated in a recirculation system.

\section{MATERIAL AND METHODS Experimental design}

The rainbow trout used in this study were raised in concrete tanks with efficient water
GEORGIEVA K., et al.

volume $0.8 \mathrm{~m}^{3}$, part of a recirculation system. Fish were divided into six groups of 20 fish each: one control (C) and five experimental groups whose feed was supplemented with curcumin (EC), paprika (EP), thyme (ET), oregano (EO) and garlic (EG). Each of trial variants was with two replications. The trouts were fed with extruded pellets produced by "Aqua garant" Co, with pellet size $3 \mathrm{~mm}$, three times per day. The feed of the fish from experimental groups was supplemented with $1 \%$ dry extract of the different spices, mentioned above. It was dissolved in $1 \mathrm{ml}$ distilled water and sprayed onto $100 \mathrm{~g}$ feed one hour before feeding. The individuals from the control group (C) did not receive any phytoextracts. Phytoextracts of paprika, thyme, oregano and garlic were produced by „Rigana“ company and curcumin extract was produced by FMS Corporation. The phytoextracts used in the experiment were supplied by „P.I.C.Co" SA company. The nutritional content of extruded feed for the different groups is presented in Table 1. The duration of the experiment was 60 days.

Table 1. Nutritional content in the trout feed

\begin{tabular}{|l|l|l|l|l|l|l|l|}
\hline \multirow{2}{*}{ № } & \multirow{2}{*}{ Parameters } & \multicolumn{6}{l}{ Experimental groups } \\
\cline { 3 - 8 } & & C & EC & EP & ET & EP & EG \\
\hline 1 & Crude protein, \% & 45.00 & 45.00 & 45.00 & 45.00 & 45.00 & 45.00 \\
\hline 2 & Crude fat, \% & 16.00 & 16.00 & 16.00 & 16.00 & 16.00 & 16.00 \\
\hline 3 & Crude fibre, \% & 2.40 & 2.40 & 2.40 & 2.40 & 2.40 & 2.40 \\
\hline 4 & Crude ash, \% & 8.00 & 8.00 & 8.00 & 8.00 & 8.00 & 8.00 \\
\hline 5 & Calcium, \% & 1.60 & 1.60 & 1.60 & 1.60 & 1.60 & 1.60 \\
\hline 6 & Phosphorus, \% & 1.20 & 1.20 & 1.20 & 1.20 & 1.20 & 1.20 \\
\hline 7 & Curcumin, \% & - & 1.00 & - & - & - & - \\
\hline 8 & Paprika, \% & - & - & 1.00 & - & - & - \\
\hline 9 & Thyme, \% & - & - & - & 1.00 & - & - \\
\hline 10 & Oregano, \% & - & - & - & - & 1.00 & - \\
\hline 11 & Garlic, \% & - & - & - & - & - & 1.00 \\
\hline 12 & Metabolisable energy, MJ/kg & 18.50 & 18.50 & 18.50 & 18.50 & 18.50 & 18.50 \\
\hline
\end{tabular}

* $1 \mathrm{~kg}$ compound feed contains: vitamin A - $10000 \mathrm{IU}$; vitamin $\mathrm{D}_{3}-1500 \mathrm{IU}$; vitamin $\mathrm{E}-200 \mathrm{mg}$; vitamin

C - $150 \mathrm{mg}$. ** $1 \mathrm{~kg}$ compound feed contains: $\mathrm{Fe}-62 \mathrm{mg}$; $\mathrm{Mn}-26 \mathrm{mg}$; Cu $-5 \mathrm{mg}$; $\mathrm{Zn}-103 \mathrm{mg}$; J $-2.6 \mathrm{mg}$; $\mathrm{Se}-0.3$. mg.

\section{Growth performance}

The effect of added phytoextracts to feed on weight gain of rainbow trouts was determined by control catches in the middle and end of the experimental period. Individual live weight $(\mathrm{g})$ was determined as the fish were weighed individually. At the end of the trial, weight gain $(\mathrm{g})$, survival rate $(\%)$ and feed conversion ratio of the different feeds were determined.

\section{Blood parameters}

Blood was taken from the examined trouts from the caudal vein with disposable sterile plastic syringes $(3 \mathrm{ml})$ with a needle. An anticoagulant EDTA (1\%) was used. The blood samples were instantly transmitted and analyzed in a hematological laboratory (NCPTC - Trakia University) and reported in Mindray BC - 120 hematology analyzer. Follow haematological and biochemical blood 
parameters were investigated: glucose $(\mathrm{mmol} / \mathrm{l})$, urea $(\mathrm{mmol} / \mathrm{l})$, creatinine $(\mu \mathrm{mol} / \mathrm{l})$, total protein $(\mathrm{g} / \mathrm{l})$, albumin $(\mathrm{g} / \mathrm{l})$, ASAT $(\mathrm{U} / \mathrm{l})$, ALAT (U/1), white blood cells ( $\left.\mathrm{x} 10^{9} 1\right)$, red blood cells $\left(\times 10^{12} 1\right)$, hemoglobin $(\mathrm{g} / \mathrm{l})$ and hematocrit (\%). The experiment was conducted in accordance with the "Guide to the Care and Use of Experimental Animal Care".

\section{Statistical evaluation}

The results were statistically evaluated to determine the effect of the phytoextracts in the diet of rainbow trout on the growth performance, chemical and fatty acid composition of the fillets. The statistical evaluation was preformed using STATISTICA 6.0 software, $\mathrm{t}$ - test, independent by variables (StatSoft Inc., 2002).

\section{RESULTS}

\section{Growth performance}

The growth parameters, feed conversation ratio and survival rate of rainbow trout from the control and all experimental groups, receiving phytoextracts are presented in Table 2.

Average initial body weight at the beginning in the groups were: $129.39 \pm 19.18 \mathrm{~g}$ (C), $132.85 \pm 15.79 \mathrm{~g}$ (EC), $134.20 \pm 21.31 \mathrm{~g}$ (EP), $130.78 \pm 21.00 \mathrm{~g}$ (ET), $131.10 \pm 15.72 \mathrm{~g}$ (EO) and $129.80 \pm 16.80 \mathrm{~g}$ (EG), with statistically insignificant differences $(\mathrm{P}>0.05)$. The final
GEORGIEVA K., et al. body weight of fish from the control group was - $254.92 \pm 61.67$ g. It was higher than those from EC and EP groups by $1.26 \%$ and $3.79 \%$, and lower by $5.19 \%$ (ET), $3.17 \%$ (EO) and $3.66 \%$ (EG), respectively. The differences among groups were insignificant $(\mathrm{P}>0.05)$.

At the end of the trial, individual weight gain of fish from ET group was the highest $141.33 \pm 32.67 \mathrm{~g}$ compared to those from control and other experimental groups by $9.03 \%$ (C), $9.98 \%$ (EC), $16.36 \%$ (EP), 2.53\% (EO) and $2.12 \%$ (EG), but the differences between groups were statistically insignificant $(\mathrm{P}>0.05)$.

Feed conversion ratio of rainbow trout, fed with extruded pellets, supplemented with thyme extract (ET) was 1.21. It is lower than respective FCR of other groups by $11.57 \%$ (C), $13.22 \%$ (EC), $13.22 \%$ (EP), $1.65 \%$ (EO) and $2.47 \%$ (EG). Significantly lower FCR was established in fish from experimental group supplemented with thyme extract (ET), compared to those from $\mathrm{C}$ group $(\mathrm{P}<0.05)$.

Survival rates of fish from control and experimental groups were as followed: $\mathrm{C}$ $90 \%, \mathrm{EC}-93 \%, \mathrm{EP}-83 \%$, ET - 90\%, EO $93 \%$, and $\mathrm{EG}-88 \%$. The value of this parameter is higher in fish from EC and EO with 3-10\% from these ones of individuals from the rest groups.

Table 2. Growth parameters of rainbow trout (Oncorhynchus mykiss W.), cultivated in a recirculation system.

\begin{tabular}{|c|c|c|c|c|c|c|c|c|c|c|c|c|}
\hline \multirow{2}{*}{$\begin{array}{l}\text { Paramet } \\
\text { er }\end{array}$} & \multirow[b]{2}{*}{$\mathbf{n}$} & C & \multirow[b]{2}{*}{$\mathbf{n}$} & $\mathbf{E C}$ & \multirow[b]{2}{*}{$\mathbf{n}$} & $\mathbf{E P}$ & \multirow[b]{2}{*}{$\mathbf{n}$} & ET & \multirow[b]{2}{*}{$\mathbf{n}$} & EO & \multirow{2}{*}{$\mathbf{n}$} & $\mathbf{E G}$ \\
\hline & & $\bar{x} \pm \mathrm{SD}$ & & $\bar{x} \pm \mathrm{SD}$ & & $\bar{x} \pm \mathrm{SD}$ & & $\bar{x} \pm \mathrm{SD}$ & & $\bar{x} \pm \mathrm{SD}$ & & $\bar{x} \pm \mathrm{SD}$ \\
\hline $\begin{array}{l}\text { Initial } \\
\text { weight } \\
(\mathrm{g})\end{array}$ & 40 & $129.39 \pm 19.18$ & 40 & $132.85 \pm 15.79$ & 40 & $134.20 \pm 21.31$ & 40 & $130.78 \pm 21.00$ & 40 & $131.10 \pm 15.72$ & 40 & $129.80 \pm 16.80$ \\
\hline $\begin{array}{l}\text { Final } \\
\text { weight } \\
(\mathrm{g})\end{array}$ & 36 & $254.92 \pm 61.67$ & 37 & $251.70 \pm 53.97$ & 33 & $245.27 \pm 49.90$ & 36 & $268.14 \pm 49.39$ & 37 & $263.00 \pm 50.94$ & 35 & $264.26 \pm 49.21$ \\
\hline $\begin{array}{l}\text { Survival } \\
\text { rate }(\%)\end{array}$ & & 90 & & 93 & & 83 & & 90 & & 93 & & 88 \\
\hline $\begin{array}{l}\text { Weight } \\
\text { gain }(g)\end{array}$ & 36 & $128.57 \pm 39.64$ & 37 & $127.23 \pm 30.54$ & 33 & $118.21 \pm 34.90$ & 36 & $141.33 \pm 32.67$ & 37 & $137.75 \pm 33.79$ & 35 & $138.34 \pm 35.88$ \\
\hline $\begin{array}{l}\text { Feed } \\
\text { conversa } \\
\text { tion ratio }\end{array}$ & 36 & $1.35 \pm 0.37^{\mathrm{a}}$ & 37 & $1.37 \pm 0.32$ & 33 & $1.37 \pm 0.32$ & 36 & $1.21 \pm 0.21^{\mathrm{a}}$ & 37 & $1.23 \pm 0.31$ & 35 & $1.24 \pm 0.34$ \\
\hline
\end{tabular}

Values with same superscripts in the same row are significantly different, a - a- $\mathrm{P} \leq 0.05$

\section{Blood parameters}

The inclusion of phytoextracts to the diet of rainbow trout had significant influence on the WBC (white blood cells) count. Its count tends to be higher in fish from the experimental groups, as compared to those from control group. The WBC count in blood of fish from control group was lower than to those from EC, EP, ET, EO, EG groups by $16.09 \%(\mathrm{P} \leq$ $0.001), 12.06 \%(\mathrm{P} \leq 0.001), 1,44 \%(\mathrm{P} \leq$ $0.001), 15.29 \%(\mathrm{P} \leq 0.001), 47.53 \%(\mathrm{P} \leq$ 0.001), respectively (Table 3). The RBC (red 
blood cells) count of the fish from $\mathrm{C}$ group was $0.07 \pm 0.02 \times 10^{12} / 1$, significantly higher vs that of ET group by $75.00 \%(\mathrm{P} \leq 0.01)$ (Table 3$)$. In the present study we observed significant increase on the hemoglobin content of fish from experimental groups. The hemoglobin content of fish from C group was $60.33 \pm 17.01$ $\mathrm{g} / \mathrm{l}$ and it was significantly lower than to those from ET and EO groups respectively, $40.89 \%$ $(\mathrm{P} \leq 0.05)$ and $45.58 \% \quad(\mathrm{P} \leq 0.01)$. The same tendency was observed in fish from EC, EP, ET, EO and EG groups, concerning the hematocrit blood content. Its value was higher in rainbow trout from experimental groups compared to those ones from a control group, with no significant differences among groups $(\mathrm{P}>0.05)$ (Table 3). The highest blood glucose level was established in fish from control group (C) - $5.76 \pm 2.30 \mathrm{mmol} / \mathrm{l}$, compared to experimental groups, receiving phitoextracts, with no significant differences among groups $(\mathrm{P}>0.05)$ (Table 3). In the present research, we found significant increase on the urea level of fish from experimental groups. The urea level of fish from C group was $0.20 \pm 0.12 \mathrm{mmol} / \mathrm{l}$ and it was significantly lower than to those from EC, EP and EO groups respectively 3.25
GEORGIEVA K., et al. $(\mathrm{P} \leq 0.001), 4.00(\mathrm{P} \leq 0.001)$ and $6.25(\mathrm{P} \leq$ 0.05 ) times (Table 3). The creatinine level of fish from control group was $19.00 \pm 0.00 \mu \mathrm{mol} / \mathrm{l}$ and it was higher than those from EP and EG groups by $31.58 \%(\mathrm{P} \leq 0.01)$ and $18.42 \%(\mathrm{P} \leq$ $0.001)$ and lower as compared to those ones from $\mathrm{EO}$, by $47.36 \%(\mathrm{P} \leq 0.05)$. The amount of plasma protein of fish from control group was $41.45 \pm 1.44 \mathrm{~g} / \mathrm{l}$ and it was significantly lower, as compared to those from ET and EG groups, respectively $17.12 \%$ and $17.49 \%(\mathrm{P} \leq$ $0.001, \mathrm{P} \leq 0.001$ ) (Table 3). The amount of albumin in the fish blood from $\mathrm{C}$ group was $25.60 \pm 1.27 \mathrm{~g} / \mathrm{l}$ and it was significantly lower, than to those from ET group by $23.04 \%$ (P $\leq$ $0.05)$.

In the present study was observed significant decrease on the ASAT values in fish from EC, $\mathrm{EO}$ and $\mathrm{EG}$ groups as compared to $\mathrm{C}$ group by 5.77 times $(\mathrm{P} \leq 0.001), 41.31 \%(\mathrm{P} \leq 0.05)$ and $34.65 \%(\mathrm{P} \leq 0.001)$, respectively (Table 3$)$. The lowest ALAT value was established in fish from $\mathrm{C}$ group - $11.00 \pm 6.93 \mathrm{U} / \mathrm{l}$, as compared to those ones from EC, EO and EG groups by $4.50(\mathrm{P} \leq 0.001), 4.77(\mathrm{P} \leq 0.01)$ and $8.27(\mathrm{P} \leq 0.05)$ times, respectively (Table 3$)$.

Table 3. Blood parameters of rainbow trout (Oncorhynchus mykiss W.), cultivated in a recirculation system

\begin{tabular}{|c|c|c|c|c|c|c|c|}
\hline $\begin{array}{l}\text { Blood } \\
\text { parameters }\end{array}$ & $\mathbf{n}$ & $\mathrm{C}$ & EC & EP & ET & EO & EG \\
\hline & & $\bar{x} \pm \mathrm{SD}$ & $\bar{x} \pm \mathrm{SD}$ & $\bar{x} \pm \mathrm{SD}$ & $\bar{x} \pm \mathrm{SD}$ & $\bar{x} \pm \mathrm{SD}$ & $\bar{x} \pm \mathrm{SD}$ \\
\hline WBC $\times 10^{9} 1$ & 6 & $187.05 \pm 0.64^{\mathrm{d}}$ & $217.15 \pm 0.64^{d}$ & $209.60 \pm 0.69^{d}$ & $189.75 \pm 0.64^{\mathrm{d}}$ & $215.65 \pm 0.64^{d}$ & $275.25 \pm 0.64^{\mathrm{d}}$ \\
\hline RBC $\times 10^{12} 1$ & 6 & $0.07 \pm 0.02^{\mathrm{c}}$ & $0.05 \pm 0.03$ & $0.05 \pm 0.02$ & $0.04 \pm 0.02^{\mathrm{c}}$ & $0.06 \pm 0.02$ & $0.04 \pm 0.03$ \\
\hline HGB g/l & 6 & $60.33 \pm 17.01^{\mathrm{ac}}$ & $79.50 \pm 15.63$ & $75.17 \pm 17.97$ & $85.00 \pm 14.66^{\mathrm{a}}$ & $87.83 \pm 9.41^{\mathrm{c}}$ & $81.00 \pm 22.61$ \\
\hline HCT \% & 6 & $17.85 \pm 3.09$ & $18.97 \pm 2.57$ & $20.32 \pm 3.80$ & $19.85 \pm 2.15$ & $19.67 \pm 3.49$ & $21.30 \pm 4.03$ \\
\hline Glu mmol/1 & 6 & $5.76 \pm 2.30$ & $3.17 \pm 0.13$ & $3.37 \pm 2.38$ & $3.91 \pm 2.18$ & $5.68 \pm 0.40$ & $3.22 \pm 1.22$ \\
\hline $\begin{array}{l}\text { Urea } \\
\mathrm{mmol} / \mathrm{l}\end{array}$ & 6 & $0.20 \pm 0.12^{\mathrm{ad}}$ & $0.65 \pm 0.06^{\mathrm{d}}$ & $0.80 \pm 0.00^{\mathrm{d}}$ & $0.35 \pm 0.06$ & $1.25 \pm 0.75^{\mathrm{a}}$ & $0.50 \pm 0.46$ \\
\hline $\begin{array}{l}\text { Crea } \\
\mu \mathrm{mol} / 1\end{array}$ & 6 & $19.00 \pm 0.00^{\mathrm{acd}}$ & $13.50 \pm 6.35$ & $13.00 \pm 2.31^{\mathrm{c}}$ & $18.50 \pm 2.89$ & $28.00 \pm 6.93^{\mathrm{a}}$ & $15.50 \pm 0.58^{\mathrm{d}}$ \\
\hline $\mathrm{TP} \mathrm{g} / \mathrm{l}$ & 6 & $41.45 \pm 1.44^{\mathrm{cd}}$ & $40.45 \pm 4.56$ & $44.05 \pm 2.37$ & $48.55 \pm 1.21^{\mathrm{d}}$ & $44.60 \pm 6.70$ & $48.70 \pm 1.85^{\mathrm{d}}$ \\
\hline $\mathrm{Alb} g / \mathrm{l}$ & 6 & $25.60 \pm 1.27^{\mathrm{a}}$ & $26.50 \pm 0.46$ & $29.35 \pm 3.98$ & $31.50 \pm 3.35^{\mathrm{a}}$ & $29.50 \pm 5.20$ & $24.30 \pm 0.92$ \\
\hline ASAT U/l & 6 & $63.50 \pm 1.73^{\mathrm{acd}}$ & $11.00 \pm 3.46^{\mathrm{d}}$ & $57.50 \pm 60.62$ & $77.50 \pm 80.25$ & $36.00 \pm 16.17^{\mathrm{a}}$ & $41.50 \pm 15.59^{b}$ \\
\hline ALAT U/1 & 6 & $11.00 \pm 6.93^{\mathrm{acd}}$ & $49.50 \pm 13.28^{d}$ & $15.00 \pm 11.55$ & $14.50 \pm 8.66$ & $52.50 \pm 16.74^{\mathrm{c}}$ & $91.00 \pm 88.91^{\mathrm{a}}$ \\
\hline
\end{tabular}

Values with same superscripts in the same row are significantly different, $a-a, b-b: p \leq 0.05 ; c-c: p \leq 0.01 ; d-d$ : $\mathrm{p} \leq 0.001$.

\section{DISCUSSION}

\section{Growth performance}

The analysis of experimental data from the present research reviled that the inclusion of curcumin, paprika, thyme, oregano and garlic extracts to the diet did not change final weight and weight gain of the rainbow trouts from experimental groups. Their values were no statistically different comparing with these ones of fish from the control group ( $\mathrm{P}>0.05)$ (Table 2). Similar results for trouts fed with different dietary garlic, oregano, ehinacea, ginger levels in the feed were reported by Nya and Austin, 2011 (18). Other authors, also 
GEORGIEVA K., et al.

observed no significant influence on the weight gain of rainbow trout (Oncorhynchus mykiss) and African catfish (Clarias gariepinus), receiving garlic supplemented feed $(4,19)$. The addition of different garlic levels to the diet of African catfish (Clarias gariepinus) did not change its growth parameters (9). According to the experimental data from the present study dietary thyme, paprika and curcumin also did not exert any influence on the growth performance of rainbow trout compared to that of non-supplemented fish. The same results also were established for Oreochromis mossambicus and Paralichthys olivaceus, received feed enriched with thyme and paprika $(20,21)$. According to the data from the present study the addition of $1 \%$ curcumin, paprika, thyme, oregano and garlic extracts had no significant influence on survival rate of fish. The results at the end of the 60-day experimental period showed that survival rate of a control group and experimental groups were no significant different $(P>0.05)$. The lower feed conversion ratio was established in the ET group vs control fish $(\mathrm{P}<0.05)$ (Table 2). The better conversion of feeds supplemented with $1 \%$ thyme, oregano and garlic had a beneficial effect on the growth of experimental fish. This was confirmed by the results of other authors having fed with oregano and garlic supplemented feed to rainbow trout and Oreochromis niloticus (3, 22). In the present study the experimental groups supplemented with curcumin and paprika extract showed the opposite tendency e.g. higher FCR than control group. On the contrary, the addition of different curcumin levels in the feed of Labeo rohita led to better feed conversation ratio (23). This was confirmed by the results of Maniat et al. (2014b) (24) having fed paprika to Masopotamichthys sharpeyi. The results of present research with rainbow trout however disagreed with them.

\section{Blood parameters}

The inclusion of phytoextracts to the diet of rainbow trout increase the WBC count. The WBC count in the blood of fish from $C$ group was significantly lower, compared to those from EC, EP, ET, EO and EG groups $(\mathrm{P} \leq$ 0.001). A number of researchers established higher WBC count in different fish species as a result of the addition of plant extracts, such as curcumin and garlic $(13,23,24,27)$. The results of present study corresponded by theirs. The data from the present study showed that the $\mathrm{RBC}$ count of the fish from $\mathrm{C}$ group was significantly higher as compared to those from ET group ( $\mathrm{P} \leq 0.01)$ (Table 3). Contrary to these results, some authors found no significant influence on this parameter to Acipenser stellatus fed with thyme supplemented feed and Oncorhynchus mykiss fed with oregano extract $(17,12)$. The addition of different curcumin levels also did not change the RBC count to Megalobrama amblycephala (13). In the present study was established tendency of significant increace on the hemoglobin content of fish from experimental groups. The hemoglobin content of fish from $\mathrm{C}$ group was significantly lower than to those from ET and EO groups $(\mathrm{P} \leq$ $0.05)(\mathrm{P} \leq 0.01)$. On the contrary, significantly lower hemoglobin content to Oreochromis niloticus fed thyme supplemented feed was established by Zaki et al. (2012) (10). According to Pourmoghim et al. (2015) (12) the inclusion of oregano to the diet of Oncorhynchus mykiss had no significant effect on the hemoglobin content. The results from the recent study were not in agreement with them. The addition of phytoextracts to the feed of trout increace the hematocrit content as compared to $\mathrm{C}$ group, but the differences among experimental groups were insignificant $(\mathrm{P}>0.05)$. For insignificant effect on the hematocrit content to Oncorhynchus mykiss, received oregano extract also reported Pourmoghim et al. (2015) (12). The analysis of experimental data from the present study showed that the addition of phytoextract had no significant effect on the blood glucose level. Although, the highest blood glucose level was established in fish from control group, compared to other experimental groups. This was confirmed by the results of Metwally, 2009 (22) for Oreochromis niloticus, received different garlic levels. In the present investigation the inclusion of phytoextracts in the diet of rainbow trout influenced significantly the urea level. The urea level of fish from $C$ group was significantly lower than to those from $\mathrm{EC}, \mathrm{EP}$ and $\mathrm{EO}$ groups, respectively $3.25(\mathrm{P} \leq 0.001), 4.00(\mathrm{P} \leq 0.001)$ and $6.25(\mathrm{P} \leq 0.05)$ times. According to Y1lmaz et al. (2012) (26) the addition of thyme had no significant effect on the urea level to Dicentrarchus labrax. In the present research was established significantly higher creatinine level of fish from $\mathrm{C}$ group as compared to those from EP and EG groups by $31.58 \%$ (P $\leq 0.01)$ and $18.42 \%(\mathrm{P} \leq 0.001)$. At the same time, it was lower compared to EO group, by $47.36 \%$, $(\mathrm{P} \leq 0.05)$. Insignificant influence on 
the creatinine level to Dicentrarchus labrax fed with thyme extract was reported by Y1lmaz et al. (2012) (26). The plasma protein of fish from C group was significantly lower as compared to those from ET and EG groups respectively, $17.12 \%$ and $17.49 \%(\mathrm{P} \leq 0.001$, $\mathrm{P} \leq 0.001)$. This was confirmed by the results of other authors having fed garlic extract to different fish species $(22,27)$. The addition of thyme to the diet of Clarias gariepinus also increases the plasma protein (28). In the present investigation the amount of albumin in the fish blood from $\mathrm{C}$ group was significantly lower, than to those from ET group by $23.04 \%$ $(\mathrm{P} \leq 0.05)$. Our results corresponded to those reported by Emerish \& El-Deen, 2016 (28) having fed thyme to Clarias gariepinus. In the present study we observed significant decrease on the ASAT values in fish from EC, EO and EG groups as compared to $\mathrm{C}$ group by 5.77 (P $\leq 0.001)$ times, $41.31 \%(\mathrm{P} \leq 0.05)$ and 34.65 $\%(\mathrm{P} \leq 0.001)$. In the present study we observed significant decrease on the ASAT values in fish from EC, EO and EG groups, than to those from $\mathrm{C}$ group by $5.77 \%$ (P $\leq$ $0.001)$ times, $41.31 \%(\mathrm{P} \leq 0.05)$ and $34.65 \%$ $(\mathrm{P} \leq 0.001)$. Our results were confirmed by those reported by Xia et al. (2015) (13) to Megalobrama amblycephala, received curcumin extract. The same effect of garlic supplementation on the ASAT values of Oreochromis niloticus was established by the results of Metwally, 2009 (22). According to experimental data, the lowest ALAT value was found in fish from $\mathrm{C}$ group. It was significantly lower as compared to those ones from EC, EO and EG groups by $4.50(\mathrm{P} \leq 0.001), 4.77(\mathrm{P} \leq$ $0.01)$ and $8.27(\mathrm{P} \leq 0.05)$ times. On the contrary, significantly decrease of the ALAT values to Oreochromis niloticus as a result of garlic supplemented feed was found by Metwally, 2009 (22). Similar results for Megalobrama amblycephala, received curcumin extract also were reported by Xia et al. (2015) (13).

\section{CONCLUSIONS}

The addition of curcumin, paprika, thyme, oregano and garlic extracts to the diet had no significant influence on the growth performance of the rainbow trout from experimental groups. The feed conversion ratio of trouts reared in a recirculation system was the lowest in the experimental group supplemented with thyme compared to control and vs the other supplemented groups.

Some of the hematological and biochemical parameters of fish blood were significantly
GEORGIEVA K., et al. influenced by the addition of phytoextracts to the diet of rainbow trout.

The addition of phytoextracts to the diet of rainbow trout increase significantly the WBC count. The WBC count in the blood of fish from $\mathrm{C}$ group was lower, compared to those from $\mathrm{EC}, \mathrm{EP}, \mathrm{ET}, \mathrm{EO}$ and $\mathrm{EG}$ groups $(\mathrm{P} \leq$ 0.001). The RBC count of the fish from $C$ group was significantly higher as compared to those from ET group $(\mathrm{P} \leq 0.01)$. The hemoglobin content of fish from $\mathrm{C}$ group also was significantly lower than those from ET and EO groups $(\mathrm{P} \leq 0.05, \mathrm{P} \leq 0.01)$. The same tendency was observed concerning the urea level in trout blood. The urea level of fish from $\mathrm{C}$ group was significantly lower than fish from $\mathrm{EC}, \mathrm{EP}$ and EO groups $(\mathrm{P} \leq 0.001, \mathrm{P} \leq 0.001$, $\mathrm{P} \leq 0.05)$. The creatinine level of fish from a control group was higher than those from EP and $\mathrm{EG}$ groups $(\mathrm{P} \leq 0.01, \mathrm{P} \leq 0.001)$ and lower as compared to those ones from EO group $(\mathrm{P} \leq$ $0.05)$. Significantly lower amount of plasma protein was established in fish from $\mathrm{C}$ group than to those from ET and EG (P $\leq$ $0.001, \mathrm{P} \leq 0.001)$. In the present investigation the amount of albumin in the fish blood from $\mathrm{C}$ group was significantly lower, compared to those from ET group $(P \leq 0.05)$. Significant decrease on the ASAT values was established in fish from EC, EO and EG groups as compared to $\mathrm{C}$ group $(\mathrm{P} \leq 0.001, \mathrm{P} \leq 0.05, \mathrm{P} \leq$ $0.001)$. The ALAT value was the lowest in fish from $\mathrm{C}$ group as compared to those ones from $\mathrm{EC}, \mathrm{EO}$ and $\mathrm{EG}$ groups $(\mathrm{P} \leq 0.001, \mathrm{P} \leq 0.01, \mathrm{P}$ $\leq 0.05$ ).

\section{REFERENCES}

1. Gabor, E., Ichim, O. and Şuteu, M., Phytoadditives in rainbow trout (Oncorhynchus mykiss) nutrition. Biharean Biologist, 6:134-139, 2012.

2. Syahidah, A., Saad, R., Daud, M. and Abdelhadi, M., Status and potential of herbal applications in aquaculture: A review. Iranian Journal of Fisheries Sciences, 14: 27-4, 2015.

3. Ahmadiar, E., Falahatkar, B. and Akrami, R., Effects of dietary thymol-carvacrol on growth performance, hematological parameters and tissue composition of juvenile rainbow trout, Oncorhynchus mykiss. Journal of Applied Ichthyology, 1 4, 2011.

4. Gabor, E., Şara, A., Molnar, F. and Benţea, M., The influence of some phytoadditives on growth performances and meat quality in rainbow trout (Oncorhynchus mykiss). 
Animal Science and Biotechnologies, 44:13 $-18,2011$.

5. Jegede, T., Effect of garlic (Allium sativum) on growth, nutrient utilization, resistance and survival of Tilapia zillii (Gervais 1852) fingerlings. Journal of Agricultural Science, 4:269-274, 2012.

6. Antache, A., Cristea, V., Grecu, I., Dediu, L., Mocanu, M., Ion, S. and Petrea, S., The effects of some phytobiotics on biochemical composition of Oreochromis niloticus meat reared in a recirculating aquaculture system. Animal science and biotechnologies, 46:238 $-243,2013$.

7. Maniat, M., Ghotbeddin, N. and Ghatrami, E., Effect of garlic on growth performance and body composition of benni fish (Mesopotamichthys sharpeyi). International Journal of Biosciences, 5:269-277, 2014a.

8. Mahmoud, H., Al-Sagheer, A., Reda, F., Mahgoub, S. and Ayyata, M., Dietary curcumin supplement influence on growth, immunity, antioxidant status, and resistance to aeromonas hydrophila in Oreochromis niloticus. Aquaculture, 475:16-23, 2017.

9. Thanikachalam, K, Kasi, M. and Rathinam, $\mathrm{X}$, Effect of garlic peel on growth, hematological parameters and disease resistance against Aeromonas hydrophila in African catfish Clarias gariepinus (Bloch) fingerlings. Asian Pacific Journal of Tropical Medicine, 3:614-618, 2010.

10.Zaki, A., Labib, M., Nour, M., Tonsy, D. and Mahmoud, S., Effect of some medicinal plants diets on mono sex nile tilapia (Oreochromis niloticus), growth performance, feed utilization and physiological parameters. Asia - Pasific chemical, biological \& enviromental engineering society, 220 - 227, 2012.

11.Manju, M., Vijayasree, A., Akbarsha, M. and Oommen, O., Protective effect of dietary curcumin in Anabas testudineus (Bloch) with a special note on DNA fragmentation assay on hepatocytes and micronucleus assay on erythrocytes in vivo. Fish physiolgy biochememistry, 39: 13231330, 2013.

12.Pourmoghim, H., Haghighi, M. and Rohani, M., Effect of dietary inclusion of Origanum vulgare extract on nonspecific immune responses and hematological parameters of rainbow trout (Oncorhynchusmykiss). Bulletin of Environment, Pharmacology and Life Sciences, vol. 4, pp. 33-39, 2015.

13.Xia, S., Ge, X., Liu, B., Xie, J., Miao, L., Ren, M., Zhou, Q., Zhang, W., Jiang, X.,
GEORGIEVA K., et al.

Chen, R. and Pan, L., Effects of supplemented dietary curcumin on growth and non-specific immune responses in juvenile Wuchang Bream (Megalobrama amblycephala). The Israeli Journal of Aquaculture - Bamidgeh, 1174: 1 - 13, 2015.

14.Saleh, N., Michael, R. and Mohamed, M., Evaluation of garlic and onion powder as phyto-additives in the diet of sea bass (Dicentrarcus labrax). Egyptian Journal of Aquatic Research, 41: 211-217, 2015.

15.Ajeel, S. and Al-Faragi, J., Effect of ginger (Zingiber officinale) and garlic (Allium sativum) to enhance health of common carp Cyprinus carpio $L$. The Iraqi journal of veterinary medicine, 37: 59-62, 2013.

16.Farahi, A., Kasiri, M., Sudagar, M., Iraei, S. and Shahkolaei, D., Effect of garlic (Allium sativum) on growth factors, some hematological parameters and body compositions in rainbow trout (Oncorhynchus mykiss). Aquaculture, Aquarium, Conservation \& Legislation, 3: 317-323, 2010.

17.Dorojan, O., Cristea, V., Ion, S. and Petrea, S., The influence of some phytobiotics (thyme, seabuckthorn) on growth performance of stellate sturgeon (A. stellatus, Pallas, 1771) in an industrial recirculating aquaculture system. Animal Science and Biotechnologies, 47:205 - 210, 2014.

18.Nya, E. and Austin, B., Development of immunity in rainbow trout (Oncorhynchus mykiss, Walbaum) to aeromonas hydrophila after the dietary application of garlic. Fish \& Shellfish Immunology 30: 845 - 850, 2011.

19.Abraham, J. and Ritu, R., Effects of dietary supplementation of garlic (Allium sativum) extract on the resistance of Clarias gariepinus against Edwardsiella tarda infection. Iranian journal of fisheries sciences, 14:719-733, 2015.

20.Yılmaz, S., Ergün, S. and Soytaş, N., Herbal supplements are useful for preventing streptococcal disease during first-feeding of Tilapia fry, Oreochromis mossambicus. The Israeli journal of aquaculture - Bamidgeh, 1-5, 2013.

21.Pham, M., Byun, H., Kim, K. and Lee, S., Effects of dietary carotenoid source and level on growth, skin pigmentation, antioxidant activity and chemical composition of juvenile olive flounder 
Paralichthys olivaceus. Aquaculture, 431:65-72, 2014.

22.Metwally, M., Effects of garlic (Allium sativum) on some antioxidant activities in Tilapia nilotica (Oreochromis niloticus). World journal of fish and marine sciences, 1:56-64, 2009.

23.Sahu, S., Das, B., Mishra, B., Pradhan, Y., Samal, S. and Sarangi, N., Effect of dietary curcuma longa on enzymatic and immunological profiles of rohu, Labeo rohita (Ham.), infected with aeromonas hydrophila.

Aquaculture Research,39:1720-1730, 2008.

24.Maniat, M., Ghotbeddin, N., Ghatrami, E. and Azaram, H., Effect of different levels of paprika on some growth factors, survival and biochemical body composition of benni fish (Mesopotamichtys sharpey). Academic journal of science, 03: 223-229, 2014b.

25.Nwabueze, A., The Effect of garlic (Allium sativum) on growth and haematological parameters of clarias gariepinus (Burchell,
GEORGIEVA K., et al. 1822). Sustainable Agriculture Research, 1:222-228, 2012.

26.Y1lmaz, S., Ergün, S. and Çelik, E., Effects of herbal supplements on growth performance of sea bass (Dicentrarchus labrax): Change in body composition and some blood parameters. Journal of Bioscience and Biotechnology, 1: 217222, 2012

27.Talpur, A. and Ikhwanuddin, M., Dietary effects of garlic (Allium sativum) on haemato-immunological parameters, survival, growth, and disease resistance against vibrio harveyi infection in asian sea bass, Lates calcarifer (Bloch). Aquaculture, 364-365: 6-12, 2012.

28.Emerish, W. and El-Deen, A., Immunomodulatory effects of thyme and fenugreek in sharptooth catfish, Clarias Gariepinus. Assiut veterinary medical journal, 62:1-7, 2016. 
GEORGIEVA K., et al. 